\title{
PENGARUH UNIT PRODUKSI, PRAKERIN DAN DUKUNGAN KELUARGA TERHADAP KESIAPAN KERJA SISWA SMK
}

\author{
Zamzam Zawawi Firdaus \\ SMK Negeri 2 Amuntai Kab. Hulu Sungai Utara Kalimantan Selatan \\ zamzam.zulian.da@gmail.com
}

\begin{abstract}
Abstrak: Pengaruh Unit Produksi, Pengalaman Prakerin dan Dukungan Keluarga Terhadap Kesiapan Kerja Siswa SMK. Penelitian ini bertujuan untuk mengetahui: (1) kesiapan kerja siswa Sekolah Menegah Kejuruan (SMK) di Kabupaten Hulu Sungai Utara, dan (2) hubungan dan pengaruh kegiatan praktik unit produksi sekolah, pengalaman praktik kerja industri dan dukungan keluarga secara sendiri-sendiri maupun bersama-sama terhadap kesiapan kerja siswa SMK. Populasi penelitian ini adalah siswa SMK kelas XII di kabupaten Hulu Sungai Utara Tahun Ajaran 2011/2012 dengan sampel sejumlah 148 siswa yang ditentukan menggunakan Tabel Krejeie Morgan. Pengambilan sample menggunakan teknik proporsional cluster random sampling. Pengumpulan data menggunakan kuesioner dengan Skala Likert dengan alternatif empat jawaban. Data variabel dianalisis dengan statistik deskriptif. Hubungan dan pengaruh setiap variabel bebas terhadap variabel terikat dianalisis dengan statistik korelasi parsial dan regresi ganda. Interprestasi hasil analisis data menggunakan taraf signifikan $p=0,05$.Hasil analisis deskriptif menunjukkan bahwa tingkat kesiapan kerja siswa SMK di Kabupaten HSU adalah sebagai berikut: sebesar 61,49\% siswa memiliki tingkat kesiapan kerja pada kategori sangat tinggi dan sebesar 37,84\% siswa memiliki tingkat kesiapan kerja pada kategori tinggi. Hasil pengujian hipotesis menunjukkan bahwa terdapat pengaruh yang signifikan antara kegiatan praktik unit produksi sekolah, pengalaman praktik kerja industry dan dukungan keluarga terhadap kesiapan kerja $\left(R^{2}=0,501\right)$. Hal ini menjelaskan bahwa kegiatan praktik unit produksi sekolah, pengalaman prakerin dan dukungan keluarga secara bersama-sama mampu menjelaskan varian kesiapan kerja siswa SMK sebesar 50,1\%.
\end{abstract}

Kata kunci: unit produksi sekolah, pengalaman praktik kerja industri

\section{THE EFFECT OF PRODUCTION ORGANIZATION, ON- THE- JOB TRAINING AND FAMILY SUPPORT ON WORK READINESS OF THE STUDENTS IN VOCATIONAL SCHOOLS}

\begin{abstract}
The Effect of Production Organization, On- the-job Training and Family Support on Work Readiness of the Students in Vocational Schools. This research was aimed to reveal: (1) the work readiness of the students of vocational high schools (VHS) in Hulu Sungai Utara (HSU) Regency and (2) the relationship and effect of school production organization activity, on-thejob training experiences and family support individually and simultaneously on the students' work readiness. The population of this research was XII grade students of vocational schools in HSU Regency in the academic year 2011/2012, and a sample of 148 students was established by using Krejeie Morgan Table. The sample was established using the proporsional cluster random sampling technique. The research data were collected using the Likert Scale questionnaire with four options. The data of variable were descriptively analyzed. The effect and correlation between the independent and dependent variables were analyzed using the partial correlation statistic and multiple regression analysis. The interpretation of the data analysis result used the significance level of $p=0.05$. The result of the descriptive analysis shows the level of students' vocational school at HSU Regency is as follows: 61.49\% of the students' have the excellent work readiness, and $37.84 \%$ of the students' have good work readiness. The hypothesis testing shows a significant effect of the school production unit organization, on-the- job training experience, and family support on work readiness $\left(R^{2}=0.501\right)$. This shows that the school production unit organization, on-the-job training experience, and family support simultaneously are able to explain the variant of the students' work readiness as much as $50.1 \%$.
\end{abstract}

Keywords: school production organization activity, on-the-job training 


\section{PENDAHULUAN}

Sekolah Menengah Kejuruan (SMK) secara substansi merupakan salah satu lembaga pendidikan kejuruan yang diselenggarakan untuk mempersiapkan calon tenaga kerja kelas menengah dalam memasuki dunia kerja dan mengembangkan sikap profesional. Peraturan Pemerintah Republik Indodesia No 17 Tahun 2010 Tentang Pengelolaan dan Penyelenggaraan Pendidikan pasal 76 menyatakan tujuan pendidikan menengah kejuruan adalah membekali peserta didik dengan kemampuan ilmu pengetahuan dan teknologi serta kecakapan kejuruan para profesi sesuai dengan kebutuhan masyarakat.

Pendapat ahli Vladimir Gasskov (2000: 5) menyatakan:

The mandate of vocational school and training manifold. first, the vocational education and tarining system should deliver both foundation and specialist skills to private individuals, enabling them to find employment or launch their own business, to work productively and adapt to different technologies, tasks and conditions.

Secara bebas dapat diartikan bahwa mandat bagi pendidikan dan latihan kejuruan, terpenting bahwa sistem pendidikan dan latihan kejuruan harus memberikan bekal keterampilan khusus untuk individu yang memungkinkan mereka untuk mencari pekerjaan atau memulai bisnis mandiri, melatih untuk bekerja produktif dan beradaptasi dengan kondisi kemajuan teknologi. Secara khusus pengertian tersebut menekankan tujuan lulusan pendidikan kejuruan disiapkan untuk memasuki dunia kerja, baik dalam menciptakan usaha mandiri maupun memasuki peluang atau lowongan kerja yang ada.
Selanjutnya pernyataan senada yang dikemukakan Clarke \& Winch (2007: 62) menyatakan pendidikan kejuruan merupakan upaya pengembangan sosial ketenagakerjaan, pemeliharaan, percepatan dan peningkatan kualitas tenaga kerja tertentu dalam rangka peningkatan produktivitas masyarakat. Berdasarkan hasil studi observasi terbatas di Kabupaten HSU, masih banyak para lulusan SMK yang belum terserap oleh dunia kerja. Namun demikian kondisi tersebut disebabkan oleh banyak faktor mulai dari individu sendiri, proses pembelajaran semasa sekolah, lingkungan sekitas dan lain sebagainya.

\section{Unit Produksi Sekolah}

SMK melalui Direktorat Pembinaan Sekolah Menengah Kejuruan Tahun 2007, dalam kebijakannya memberikan fasilitas program untuk pengembangan program unit produksi sekolah, dengan salah satu tujuannya menjadikan SMK sebagai wahana kegiatan praktik pendidikan dan latihan yang berorientasi pada dunia kerja. Dengan asumsi bahwa SMK sebagai institusi lembaga pendidikan formal yang melakukan proses pembelajaran berbasis dunia kerja yang sangat mungkin menghasilkan produk maupun jasa yang layak dijual dan mampu bersaing di pasar kerja. Upaya tersebut selaras dengan prinsip filosofi pendidikan kejuruan yang dikemukakan oleh Charles Prosser (www.tamu-commerce.edu $)$ dalam prinsip pertamanya menyatakan bahwa

Career \& Technology $(C \& T)$ education will be efficient in proportion as the environment in which the learner is trained is a replica of the environment in which he must subsequently work. 
Oleh karena itu, SMK sangat perlu menciptakan dan mengembangkan suasana belajar bekerja nyata, dalam hal ini melalui kegiatan praktik unit produksi dan jasa di lingkungan SMK. Kegiatan praktik kerja nyata yang relevan dengan program keahlian dan tuntutan pasar kerja sangat perlu bagi siswa SMK sebagai wahana replika kerja di dunia SMK.

Menurut Martubi (1998: 30) yang dimaksud dengan unit produksi sebagai mana yang tertuang dalam pengembangan unit produksi di sekolah adalah: unit produksi merupakan usaha yang menghasilkan sesuatu barang maupun jasa, yang secara mutlak memerlukan seperangkat alat usaha sebagai modal. Bentuk usaha dalam hal ini adalah suatu sistem yang terkait antara satu komponen dengan komponen lain. Sistem tersebut pada dasarnya terdiri dari input, proses, dan output yang menuntut proses pengelolaan secara profesional.

Apabila diamati secara seksama, kegiatan praktik di unit produksi sekolah lebih menekankan pada proses pemebelajaran siswa melalui kegiatan paktek langsung dalam pekerjaan nyata (learning by doing) dalam lingkup kegiatan pembelajaran di sekolah. Model pembelajaran tersebut identik dengan model Pembelajaran Berbasis Produksi (PBP). Menurut Pardjono dan Murdianto, tujuan pembelajaran berbasis produksi antara lain yaitu: 1) membekali siswa dengan kompetensi yang sesuai dengan tuntutan dunia kerja, sekaligus menghasilkan produk atau jasa yang laku dijual 2) menanamkan pengalaman produktif dan mengembangkan sikap wirausaha, melalui pengalaman langsung memproduksi barang atau jasa yang berorientasi pada pasar. Finch \& Crunkilton (1999: 11) menyatakan

Learning and personal growth do not take place strictly within the confines of a classroom or laboratory. Student develop skills and competence through a variety of learning activities and experiences that may not necessarily be counted as constructive credit for graduation.

Secara bebas diartikan,bahwa belajar dan mengembangkan kepribadian tidak hanya terbatas di kelas dan laboratorium. Siswa dapat mengembangkan keterampilan dan kemampuannya melalui berbagai kegiatan pembelajaran dan pengalaman yang tidak memerlukan hitungan kredit seperti halnya lulusan lembaga pendidikan.

Menurut Cunningham, Dawes \& Bennett (2004: 56) model pembelajaran melalui tindakan merupakan strategi pengembangan dalam pembelajaran berbasis kerja. Lebih lanjut pembelajaran melalui tindakan merupakan model pendekatan pembelajaran dimana seorang individu dengan yang lain dalam satu kelompok kecil belajar bersama untuk menyelesaikan permasalahan yang penting, melalui proses dan penyelesaian masalah yang dilakukan mereka belajar untuk menyelesaikan masalalah yang ada.

Berdasarkan Pedoman Manajemen

Pelaksanaan Unit Produksi (2007: 7), penyelenggaraan Unit Produksi SMK dan MAK mempunyai beberapa tujuan, 6 (enam) diantaranya adalah:

1. Memberikan kesempatan kepada siswa dan guru untuk mengerjakan praktek yang berorientasi pada pasar di lingkungan sekolah. 
2. Menumbuhkan dan mengembangkan jiwa wirausaha guru dan siswa pada sekolah menengah kejuruan.

3. Membantu pendananaan untuk pemeliharaan, penambahan fasilitas dan biaya-biaya operasional pendidikan lainnya.

4. Melatih untuk berani mengambil resiko dengan perhitungan yang matang.

5. Meningkatkan kreativitas dan inivasi dikalangan siswa, guru dan manajemen sekolah.

Unit produksi Sekolah sebagai tempat magang bagi siswa praktik kerja industri yang tidak mendapat tempat di dunia kerja dan industri.

\section{Pengalaman Prakerin}

Praktik Kerja Industri (Prakerin) merupakan bagian dari pendidikan sistem ganda yang merupakan inovasi pendidikan SMK yang mana siswa melakukan magang (apprenticeship) di industri yang relevan dengan program keahliannya selama kurun waktu tertentu. Model pendidikan sistem ganda (dual system) merupakan system yang cukup efektif untuk mendidik dan menyiapkan seseorang untuk memperdalam dan menguasai keterampilan yang rumit yang tidak mungkin atau tidak pernah dilakukan di sekolah (Pardjono, 2011: 34). Dalam proses pendidikannya sistem ganda ini peserta didik selain belajar secara formal dalam pekerjaan yang sebernarnya di dunia usaha dan industri. Di Indonesia dimulai model pendidikan sistem ganda sejak Tahun 1994, dilanjutkan dengan kurikulum SMK edisi 1999, dan diperkuat melalui kurikulum SMK edisi 2004 hingga saat ini. Pelaksanaan program pemagangan di SMK saat ini dapat dimulai pada tingkat XI dan XII dengan kurun waktu kurang lebih tiga sampai enam bulan efektif di dunia kerja.

Penerapan model Pendidikan Sistem Ganda (PSG) dalam hal ini prakerin, secara esensi identik dengan strategi pembelajaran berbasis dunia kerja, seperti pendapat yang dikemukakan Raelin (2008: 2) mengatakan bahwa pembelajaran berbasis dunia kerja merupakan penggabungan pembelajaran teori dengan praktik dan pengetahuan dengan pengalaman. Siswa dapat belajar langsung dari pengalaman praktik yang terencana sesuai dengan program keahlian yang diminati. Ahli lain menurut David \& Solomon (2001: 5) menegaskan bahwa pembelajaran berbasis pekerjaan merupakan salah satu model pembelajaran yang bertujuan untuk mengintergrasikan mata pelajaran akademik dengan keterampilan yang berhubungan dengan pekerjaan. Selanjutnya model pembelajaran berbasis pekerjaan secara sistematis memiliki enam karakteristik antara lain: (1) kemitraan antara organisasi eksternal dan sebuah lembaga pendidikan khusus didirikan untuk membantu pembelajaran, (2) peserta didik terlibat layaknya karyawan, (3) program diikuti berasal dari kebutuhan tempat kerja, (4) proses pengakuan kompetensi setelah peserta didik terlibat dalam kegiatan secara utuh menurut ukuran dunia kerja, (5) proyek-proyek pembelajaran yang dilakukan di tempat kerja,dan (6) lembaga pendidikan menilai hasil pembelajaran dari program dinegosiasikan sehubungan dengan kerangka kerja standar. Dengan demikian siswa dapat mengetahui tugas-tugas khusus selain keterampilan pribadi dan pengetahuan akademik 
dan sikap yang dilakukan layaknya seorang karyawan di tempat kerjanya, sehingga kelak siswa memiliki gambaran secara pasti tentang dunia kerja dan dapat mempersiapkan diri lebih baik lulus dan memasuki dunia kerja.

Model pendidikan sistem ganda dalam pendidikan SMK, dengan konsep seperti yang diuraikan di atas, dapat dikategorikan sebagai inovasi pendidikan kejuruan yang mengandung makna perbaikan dan penyempurnaan system lama yang bersifat konvensional. Sehingga makna tujuan program system ganda secara lingkup lebih sempit (individu) akan memberikan manfaat antara lain:

1. Memberikan bekal keahlian yang profesional untuk terjun kelapangan kerja dan untuk bekal pengembangan dirinya secara berkelanjutan;

2. Rentang waktu untuk mencapai keahlian professional lebih singkat, karena setelah tamat prakerin tidak perlu latihan lanjutan untuk mencapai keahlian siap pakai;

3. Keahlian yang diperoleh dari program prakerin dapat mengangkat harga dan percaya diri dalam mendorong mereka untuk meningkatkan keahliannya pada tingkat yang lebih tinggi, Wardiman (1998: 90).

\section{Dukungan Keluarga}

Menurut hasbullah (2006: 38) lingkungan keluarga adalah lingkungan pendidikan anak yang pertama, karena dalam keluarga inilah anak pertamakali memperoleh pendidikandan bimbingan, juga dikatakan utama karena sebagian besar dari kehidupan anak adalah dalam keluarga. Lebih lanjut melalui lingkungan keluarga dapat berfungsi dan peranan sebagai berikut: (1) pengalaman pertama masa kanakkanak yang mana keluarga memberikan pengalaman pertama yang merupakan faktor penting dalam mengembangkan pribadi anak. Suasana pendidikan keluarga ini sangat penting diperhatikan, sebab dari sinilah keseimbangan jiwa di dalam perkembangan individu selanjutnya ditentukan; (2) menjamin kehidupan emosional anak, sebab emosi merupakan salah satu faktor yang terpenting dalam membentuk pribadi seseorang. Adanya kelainan di dalam perkembangan pribadi individu yang disebabkan oleh perkembangannya kehidupan emosional yang wajar; (3) menanamkan dasar pendidikan moral, keluarga merupakan aspek utama dalam menenamkan dasar-dsar moral bagi anak yang bisa tercermin dalam sikap dan perilaku orang tua sebagai suri tauladan yang dapat dicontoh anak; (4) memberikan dasar pendidikan sosial, melalui kehidupan keluarga yang penuh rasa tolong menolong, kasih saying dan gotong royong, akan memupuk benih-benih kesadaran social yang tinggi; (4) peletakan dasar-dasar keagamaan, keluarga melalui kebersamaan dalam membawa anaknya untuk beribadah ke masjid merupakan langkah bijak dalam dalam membentuk anak dalam kehidupan religi Hasbullah (2006: 39-43).

Grant \& Ray (2010: 48) mendefinisikan bahwa

Family support is a set of beliefs and an approach to strengthening and empowering families, which will positively affect children's development and learning ".

Lebih lanjut dukungan keluarga tersebut antara lain dapat berupa: (1) jaminan kesejahteraan hidup anak; (2) jaminan kesehatan anak; (2) pengakuan dari penerus sistem ekologi; (4) 
pemahaman karakter, keterampilan, budaya dan adat; (5) membantu mempromosikan dalam membangun kapasitas dan kekuatan hidup; (6) mengikuti tahap perkembangan anak dan kebuthan yang unik dan; (7) memberikan akses informasi dan layanan untuk kesejahteraannya.

\section{Kesiapan Kerja}

Ahli lain menurut Judith O. Wagner (2006: 1) mengatakan kesiapan kerja adalah sperangkat keterampilan dan perilaku yang diperlukan untuk bekerja dalam pekerjaan apa pun bentuknya. Keterampilan kesiapan bekerja kadang-kadang disebut soft skills, keterampilan kerja, atau keterampilan kesiapan kerja. Dari keragaman pengertian atau didefinisikan secara esensi keterampilan kesiapan bekerja secara makna pada prinsipnya sama. Kesiapan kerja menurut Wagner meliputi beberapa aspek antara lain: (1) kemampuan membaca untuk informasi; (2) diterapkan matematika; (3) menulis bisnis, (4) menulis, mencari informasi; (5) kerja sama tim; (6) pengamatan; (7) mendengarkan; dan (7) teknologi terapan”.

\section{Menurut Wardiman (1998: 30)} menjelaskan beberapa keterampilan yang perlu dimiliki oleh siswa SMK menjelang memasuki dunia kerja antara lain: (1) memiliki keterampilan dasar dan penyesuaian diri dengan perkembangan IPTEK; (2) mampu mencari informasi; (3) mampu mengkomunikasikan ide; (4) mampu mengorganisasi kegiatan; (5) mampu bekerjasama; (6) mampu memecahkan masalah; (7) berfikir logis dan; (8) mampu berbahasa global.
Customers Service Institute Of Australia (2005: 1), menyatakan bahwa: "Work readiness can be viewed as a both $a$ process and a goal that involves developing a student's workplace-related attitudes, value, knowledge and and skills. This enables student to become increasingly aware and confident of their role and responabilities,...

Secara bebas dapat bermakna bahwa kesiapan kerja dapat dilihat sebagai suatu proses dan tujuan yang melibatkan pengembangan kerja siswa yang berhubungan dengan sikap, nilai, pengetahuan dan, keterampilan. Hal ini memungkinkan siswa untuk menjadi semakin sadar dan yakin akan peran dan tanggungjawab mereka. Oleh karena itu proses pengembangannya perlu dilakukan secara sistematis dan terencana yang tertuang dalam suatu rencana kesiapan kerja.

Selanjutnya Menurut Zirkle (1998: 4-5) menyatakan bahwa

Employability skills: decision making skills, creative thingking skills, team work skills, leadership skills, and negotiation skills.

Secara bebas berarti bahwa keterampilan kerja meliputi: mampu membuat keputusan, mampu memecahkan suatu masalah, berfikir kreatif, mampu bekerjasama, mampu memimpin, dan mampu bernogosiasi. Lebih lanjut melengkapi keterampilan yang disebutkan di atas, Zirkle juga mengemukakan kemampuan akademik yang meliputi: kemampuan membaca, menulis, kemampuan dasar berhitung dan kemampuan berkomunikasi lisan.

\section{METODE}

Penelitian ini merupakan penelitian Ex post facto, yang mana data dalam penelitian ini diperoleh dari data peristiwa yang telah berlangsung dan peneliti tidak memanipulasi 
keadaan variable yang ada, dengan kata lain peneliti mengumpulkan fakta-fakta melalui pengukuran terhadap gejala yang telah terjadi sebelumnya dan mencari penyebabnya. Tempat penelitian ini dilaksanakan di seluruh SMK SeKabupaten Hulu Sungai Utara (HSU) Provinsi Kalimantan Selatan yang berjumlah 5 SMK dengan rincian 3 (tiga) SMK Negeri dan 1 (satu) SMK Swasta. Adapun penelitian akan dilaksanankan pada semester genap Tahun pelajaran 2012 dimulai Bulan Februari sampai dengan Bulan April 2012. Populasi penelitian ini adalah seluruh siswa yang terlibat dalam kegiatan unit produksi sekolah dan telah tuntas melaksanakan program prakerin. Dari total populasi sebanyak 240 (dua ratus empat puluh) siswa kelas XII, diperoleh sebanyak 148 sampel melalui teknik proportional Cluster Random Sampling dengan taraf signifikansi sebesar 5\% Issac dan Michael (1981: 192-193). Teknik pengumpulan data adalah cara-cara yang digunakan untuk menumpulkan data. Teknikteknik yang digunakan dalam penelitian ini adalah dengan metode berikut: 1) Observasi; 2) Dokmentasi; 3) Wawancara dan; 4) Angket menggunakan Skala Likert dengan alternatif empat jawaban. Angket penelitian sebelum digunakan divalidasi ahli dan diujicobakan pada 30 siswa untuk menguji validitas dan reliabilitas instrument. Teknik analisis data dengan menggunakan statistik deskriptif dan inferensial (regresi ganda) menggunakan program SPSS for Windows 17, yang sebelumnya data telah melalui uji prasyarat analisis antara lain: uji normal, linier, multikolinier dan, heteroskedastisitas.

\section{HASIL PENELITIAN DAN PEMBAHASAN}

Dari hasil penelitian yang dianalisis secara deskriptif menunjukkan bahwa kesiapan kerja siswa SMK dipengaruhi oleh variabel kegiatan praktik unit produksi sekolah, pengalaman prakerin dan dukungan keluarga. Dalam penelitian ini ditemukan bahwa, kesiapan kerja siswa SMK di Kabupaten HSU kelas XII menunjukan kecendrungan yang positif. Hal ini dapat diketahui dari skor rerata dari 148 orang siswa sebagai sampel responden, terdapat 91orang (61,49\%) tergolong memiliki tingkat kesiapan kerja yang positif pada kategori sangat tinggi dan 56 orang $(37,84 \%)$ tergolong memiliki tingkat kesiapan kerja kategori tinggi.

Variabel kegiatan praktik unit produksi sekolah di Kabupaten HSU dapat disimpulkan pada kategori kurang baik, hal ini dapat diketahui dari 148 orang siswa sebagai sampel responden, terdapat 88 orang (59.46\%) menyatakan kondisi kegiatan praktik unit produksi sekolah pada kategori sangat baik dan 60 orang $(40.54 \%)$ menyatakan kondisi kegiatan praktik unit produksi sekolah pada kategori baik. Hal ini dapat dijadikan evaluasi bagi sekolah, bagaimana mewujudkan sarana kegiatan praktik unit produksi sekolah yang profesional dan sistematis. Sehingga melalui kegiatan unit produksi sekolah yang baik selain dapat manfaat ekonomi bagi warga sekolah, juga akan memperoleh sarana pembelajaran berbasis kerja bagi siswa khususnya.

Variabel pengalaan prakerin siswa SMK di Kabupaten HSU termasuk pada kategori baik, hal ini dapat diketahui dari 148 orang siswa sebagai sampel responden, terdapat 82 orang $(55,4 \%)$ menyatakan kondisi kegiatan prakerin pada kategori sangat baik dan 64 orang 
$(43,24 \%)$ menyatakan kondisi kegiatan prakerin pada kategori baik. Variabel dukungan keluarga di Kabupaten HSU termasuk pada kategori kurang baik, hal ini dapat diketahui 148 orang siswa sebagai sampel responden, terdapat 92 orang $(62,16 \%)$ menyatakan dukungan keluarga pada kategori sangat baik dan 54 orang $(36,49 \%)$ menyatakan dukungan keluarga pada kategori baik.

Hasil korelasi parsial antara variabel $\mathrm{X}$ terhadap Y dapat disajikan pada tabel di bawah ini.

Tabel 1. Hasil Korelasi Parsial

\begin{tabular}{llcccc}
\hline \hline & & Unit Produksi & Prakerin & Orang tua & Kesiapan \\
\hline \hline UPS & Pearson Correlation & 1 & $0,626^{* *}$ & $0,484^{* *}$ & $0,564^{* *}$ \\
& Sig. (2-tailed) & & 0,000 & 0,000 & 0,000 \\
& $\mathrm{~N}$ & 148 & 148 & 148 & 148 \\
Prakerin & Pearson Correlation & $0,626^{* *}$ & 1 & $0,477^{* *}$ & $0,634^{* * *}$ \\
& Sig. (2-tailed) & 0,000 & & 0,000 & 0,000 \\
& N & 148 & 148 & 148 & 148 \\
D Kelrga & Pearson Correlation & $0,484^{* *}$ & $0,477^{* *}$ & 1 & $0,567^{* *}$ \\
& Sig. (2-tailed) & 0,000 & .000 & & 0,000 \\
& N & 148 & 148 & 148 & 148 \\
Kesiapan & Pearson Correlation & $0,564^{* *}$ & $0,634^{* *}$ & $0,567^{* *}$ & 1 \\
& Sig. (2-tailed) & 0,000 & 0,000 & 0,000 & \\
& N & 148 & 148 & 148 & 148 \\
\hline
\end{tabular}

**. Correlation is significant at the 0.01 level (2-tailed).

Berdasarkan tabel 01 di atas nilai korelasi ketiga variabel bebas terhadap variabel terikat $r$ $>0,50$ pada taraf sig $\mathrm{p}<0,05$, hal ini berarti kekuatan hubungan dari masing-masing variabel bebas terhadap variabel terikat termasuk pada kategori kuat dan signifikan.

Hasil analisis regresi ganda dengan bantuan program SPSS 17 For Windows metode stepwise dapat dilihat pada tabel 2 di bawah ini.

Dari uji anova ( $F$ test) tabel 02 di atas pada model 3 (tiga), diperoleh taraf signifikansi dari ketiga variabel bebas sebesar 0,000. Karena nilai $\mathrm{p}<0,05$, maka dapat disimpulkan bahwa model regresi ganda dengan variabel kegiatan praktik unit produksi sekolah, pengalaman prakerin dan dukungan keluarga terhadap kesiapan kerja siswa SMK secara bersama-sama dinyatakan layak.

Untuk menggambarkan persamaan model regresi ganda, nilai koefisien regresi dapat dilihat pada tabel 3 . 
Tabel 2. Hasil Analisis Regresi Ganda

\begin{tabular}{llccccc}
\hline \hline & Model & Sum of Squares & df & Mean Square & F & Sig. \\
\hline \hline 1 & Regression & 1931,221 & 1 & 1931,221 & 98,079 & $0,000^{\mathrm{a}}$ \\
& Residual & 2874,806 & 146 & 19,690 & & \\
& Total & 4806,027 & 147 & & & \\
2 & Regression & 2367,227 & 2 & 1183,614 & 70.372 & $0,000^{\mathrm{b}}$ \\
& Residual & 2438,800 & 145 & 16,819 & & \\
& Total & 4806,027 & 147 & & & \\
& Regression & 2459,002 & 3 & 819,667 & 50.290 & $0,000^{\mathrm{c}}$ \\
& Residual & 2347,025 & 144 & 16,299 & & \\
Total & 4806,027 & 147 & & & \\
\hline
\end{tabular}

a. Predictors: (Constant), Pengalaman Prakerin

b. Predictors: (Constant), Pengalaman Prakerin, Dukungan Keluarga

c. Predictors: (Constant), Pengalaman Prakerin, Dukungan Keluarga, UP

d. Dependent Variable: Kesiapan kerja

Tabel 3. Hasil Koefisien Regresi Ganda $X_{1}, X_{2}, X_{3}$ terhadap $\mathrm{Y}$

\begin{tabular}{|c|c|c|c|c|c|c|}
\hline & \multirow[t]{2}{*}{ Model } & \multicolumn{2}{|c|}{$\begin{array}{l}\text { Unstandardized } \\
\text { Coefficients }\end{array}$} & \multirow{2}{*}{$\begin{array}{c}\begin{array}{c}\text { Standardized } \\
\text { Coefficients }\end{array} \\
\text { Beta }\end{array}$} & \multirow[t]{2}{*}{$\mathrm{t}$} & \multirow[t]{2}{*}{ Sig. } \\
\hline & & B & Std. Error & & & \\
\hline \multirow[t]{2}{*}{1} & (Constant) & 32,757 & 3,736 & & 8,767 & 0,000 \\
\hline & P Prakerin & 0,622 & 0,063 & 0,634 & 9,903 & 0,000 \\
\hline \multirow[t]{3}{*}{2} & (Constant) & 20.267 & 4,236 & & 4,785 & 0,000 \\
\hline & P Prakerin & 0,461 & 0,066 & 0,470 & 6,991 & 0,000 \\
\hline & D Keluaraga & 0,391 & 0,077 & 0,343 & 5,091 & 0,000 \\
\hline \multirow[t]{4}{*}{3} & (Constant) & 16,745 & 4,426 & & 3,784 & 0,000 \\
\hline & P Prakerin & 0,369 & 0,076 & 0,376 & 4,875 & 0,000 \\
\hline & D Keluarga & 0,340 & 0,078 & 0,298 & 4,334 & 0,000 \\
\hline & UPS & 0,199 & 0,084 & 0,184 & 2,373 & 0,019 \\
\hline
\end{tabular}

a. Dependent Variable: Kesiapan Kerja

$$
\begin{array}{lll}
\hline \text { keterangan } & X_{1}: \text { Kegiatan praktik unit produksi sekolah } \\
X_{2} & : \text { Pengalaman Parekrin } \\
X_{3} & : \text { Dukungan Keluarga } \\
\mathrm{Y} & : \text { Kesiapan kerja }
\end{array}
$$


Pengaruh kegiatan praktik unit produksi sekolah, pengalaman prakerin dan dukungan keluarga secara secara bersama-sama berdasarkan hasil analisis regresi ganda diperoleh nilai koefisien ke arah positif, untuk kegiatan praktik unit produksi sekolah sebesar 0.199 , pengalaman prakerin sebesar 0,340 dan, dukungan keluarga sebesar 0,369 dengan konstanta 16,745 pada taraf $p<0,05$. Adapun dari nilai yang diperoleh dapat dimasukkan dalam persamaan model regresi ganda sebagai berikut.

$$
\begin{aligned}
\mathrm{Y}= & 16,745+0,199 X_{1}+0,369 X_{2}+ \\
& 0,340 X_{3}
\end{aligned}
$$

Persamaan di atas memberikan gambaran sebagai berikut:
1. Jika setiap kali variabel kegiatan praktik unit produksi sekolah bertambah satu, maka rerata nilai variabel kesiapan kerja akan bertambah nilainya sebesar 0,199.

2. Jika setiap kali variabel pengalaman prakerin bertambah satu, maka rerata nilai variabel kesiapan kerja akan bertambah nilainya sebesar 0,369 .

3. Jika setiap kali variabel dukungan keluarga bertambah satu, maka rerata nilai variabel kesiapan kerja akan bertambah nilainya sebesar 0,340 .

Selanjutnya kontribusi masing-masing variabel bebas terhadap kesiapan kerja siswa SMK di kabupaten HSU, dapat ditinjau dari hasil analisis regresi ganda pada tabel 4 berikut.

Tabel 4. Kontribusi masing-masing Variabel X Terhadap Y

\begin{tabular}{ccccc}
\hline \hline Model & $\mathrm{R}$ & R Square & $\begin{array}{c}\text { Adjusted R } \\
\text { Square }\end{array}$ & $\begin{array}{c}\text { Std. Error of } \\
\text { the Estimate }\end{array}$ \\
\hline \hline 1 & 0,634 & 0,402 & 0,398 & 4,43739 \\
2 & 0,702 & 0,493 & 0,486 & 4,10114 \\
3 & 0,715 & 0,512 & 0,501 & 4,03718 \\
\hline
\end{tabular}

a. Predictors: (Constant), Prakerin

b. Predictors: (Constant), Prakerin, Ortu

c. Predictors: (Constant), Prakerin, Ortu, UP

Berdasarkan hasil analisis regresi ganda pada tabel 04 di atas dapat dihitung kontribusi masing masing variabel bebas dengan cara mengurangkan nilai Adjusted $\mathrm{R}$ Square ruas bawah terhadap ruas atas. Model pertama kontribusi variabel pengalaman prakerin terhadap kesiapan kerja siswa SMK. Model kedua kontribusi pengalaman prakerin dengan dukungan orangtua terhadap kesiapan kerja siswa SMK. Model ketiga kontribusi pengalaman prakerin, dan dukungan keluarga terhadap kesiapan kerja siswa SMK. Adapun hasil perhitungan yang diperoleh dapat disajikan pada tabel 5 di bawah ini. 
Tabel 5. Hasil perhitungan kontribusi masing masing variabel $\mathrm{X}$ terhadap $\mathrm{Y}$

\begin{tabular}{ccccc}
\hline \hline Variabel bebas & $\begin{array}{c}\text { Adjusted R } \\
\text { Square }\end{array}$ & R Square & Signifikansi & Keterangan \\
\hline \hline $\boldsymbol{X}_{\mathbf{2}}$ & 0,039 & 0,402 & 0,000 & Berarti \\
$\boldsymbol{X}_{\mathbf{3}}$ & 0,088 & 0,091 & 0,000 & Berarti \\
$\boldsymbol{X}_{\mathbf{1}}$ & 0,015 & 0,019 & 0,000 & Berarti \\
Total & 0,501 & 0,512 & & \\
\hline
\end{tabular}

Keterangan:

$X_{1}$ : Kegiatan praktik unit produksi sekolah

$X_{3}$ : Dukungan keluarga

$X_{2}$ : Pengalaman prakerin

$\mathrm{Y}:$ Kesiapan kerja

Dari tabel 5 di atas, menunjukkan bahwa hasil analisis regresi ganda pada variabel kegiatan praktik unit produksi sekolah $X_{1}$ diperoleh Adjusted R Square sebesar 0,015 pada taraf $\mathrm{p}<0,05$, ini berarti bahwa sumbangan pengaruh kegiatan praktik unit produksi sekolah terhadap kesiapan kerja siswa SMK di Kabupaten HSU dinyatakan berarti dengan kontribusi sebesar $1.5 \%$. Hasil analisis regresi ganda pada variabel pengalaman praktik kerja industri $X_{2}$ diperoleh Adjusted $\mathrm{R}$ Square sebesar 0,398 pada taraf $\mathrm{p}<0,05$, ini berarti bahwa sumbangan pengaruh pengalaman praktik kerja industri terhadap kesiapan kerja siswa SMK di Kabupaten HSU dinyatakan berarti dengan kontribusi sebesar 39,8\%. Hasil analisis regresi ganda pada variabel dukungan keluarga $X_{3}$ diperoleh Adjusted R Square sebesar 0,088 pada $\mathrm{p}<0,05$, ini berarti bahwa sumbangan pengaruh dukungan keluarga terhadap kesiapan kerja siswa SMK di Kabupaten HSU dinyatakan berarti dengan kontribusi sebesar 8,8\%.

\section{KESIMPULAN}

Berdasarkan hasil penelitian yang sudah dibahas pada bab IV, maka dapat disimpulkan hasil penelitian ini sebagai berikut:
Pertama, beradasarkan deskripsi data hasil penelitian, kesiapan kerja siswa SMK di Kabupaten HSU memberikan gambaran yang cukup bagus, karena sebesar 19,59\% siswa kondisi kesiapan kerja siswa SMK pada kriteria sangat tinggi, 41,89\% siswa menyatakan bahwa kondisi kesiapan kerja siswa SMK pada kriteria tinggi. Dari total kategori sangat tinggi dan tinggi berjumlah $61,48 \%$, yang mana jumlah tersebut berarti lebih dari sebagian jumlah pengamatan, kesiapan kerja siswa SMK sudah sangat positif dan menggembirakan.

Kedua, hasil analisis korelasi parsial dan regresi sederhana antara kegiatan praktik unit produksi sekolah terhadap kesiapan kerja siswa SMK di Kabupaten HSU, menunjukkan nilai yang positif dan signifikan. Hal ini dapat disimpulkan bahwa pengaruh kegiatan praktik unit produksi sekolah dengan kesiapan kerja siswa SMK cukup berarti.

Ketiga, hasil analisis korelasi parsial dan regresi sederhana antara pengalaman prakerin terhadap kesiapan kerja siswa SMK di Kabupaten HSU, menunjukkan nilai positif dan signifikan. Hal ini dapat disimpulkan bahwa pengaruh pengalaman prakerin dengan kesiapan kerja siswa SMK cukup berarti. 
Keempat, hasil analisis korelasi parsial dan regresi sederhana antara dukungan keluarga terhadap kesiapan kerja siswa SMK di Kabupaten HSU, menunjukkan nilai positif dan signifikan. Hal ini dapat disimpulkan bahwa pengaruh dukungan keluarga dengan kesiapan kerja siswa SMK cukup berarti.

Kelima, hasil analisis regresi ganda dengan metode stepwise, dengan memasukkan variabel kegiatan praktik unit produksi sekolah, pengalaan prakerin dan dukungan keluarga secara bersama-sama terhadap kesiapan kerja siswa SMK di Kabupaten HSU, menunjukkan nilai positif dan signifikan. Hal ini dapat disimpulkan bahwa pengaruh kegiatan praktik unit produksi sekolah, pengalaan prakerin dan dukungan keluarga secara bersama-sama terhadap kesiapan kerja siswa SMK di Kabupaten HSU adalah berarti. Hasil analisis regresi ganda dari ke tiga variabel bebas menunjukkan kontribusi sebesar 0,501, dengan taraf signifikan $\mathrm{p}<0,05$. Ini berarti bahwa pengaruh kegiatan praktik unit produksi sekolah, pengalaan prakerin dan dukungan keluarga secara bersama-sama memberikan sumbangan terhadap kesiapan kerja siswa SMK di Kabupaten HSU sebesar 50,1\%.

\section{SARAN}

Berdasarkan pembahasan simpulan penelitian ini, maka dapat diajukan beberapa saran guna membangun kesiapan kerja siswa SMK di Kabupaten HSU antara lain

1. Hasil penelitian ini menunjukkan tingkat kesiapan kerja siswa SMK yang baik, hal ini upaya sinergis untuk dipertahankan dan lebih ditingkatkan oleh semua pihak antara lain, orang tua, sekolah, masyarakat dan pemerintah dengan jalan memberikan bimbingan dan pembinaan secara terus menerus dan berkesinambungan.

2. Ke depan kegiatan unit produksi sekolah perlu perhatian dari seluruh warga sekolah, agar manajemen kegiatan bisa lebih sistematis dan profesional.

3. Sekolah perlu menjalin kerja yang sinergis dengan pihak industri, dalam rangka mencari tempat prakerin yang layak dan relevan dengan program keahlian yang diselenggarakan.

4. Ke depan sangat perlu orang tua siswa di Kabupaten HSU meningkatkan dukungannya baik secara moral dan finansial bagi anak-anaknya.

5. Terakhir perlu adanya penelitian lanjutan guna mengungkap variabel-variabel lain yang dominan, untuk meningkatkan kesiapan kerja siswa SMK di Kabupaten HSU misalnya: variabel pendidikan wirausaha di SMK, prestasi siswa, bakat, minat dan lain sebagainya. Sehingga dapat diketahui seberapa jauh variabel tersebut mempengaruhi kesiapan kerja siswa SMK di Kabupaten HSU.

\section{UCAPAN TERIMA KASIH}

Puji syukur pada Allah SWT yang telah memberi segala kemudahan sehingga penelitian ini berhasil diselesaikan dengan baik. Selain itu perlu kiranya penulis mengucapkan terima kasih yang tak terhingga pada:

1. Pemerintah Propinsi Kalimantan Selatan dan Pemerintah Kabupaten HSU yang telah memberi kesempatan penulis untuk studi lanjut. 
2. Jajaran pimpinan, seluruh dosen dan staf Program Pascasarjana Universitas Negeri Yogyakarta yang telah memberi layanan dan fasilitas pendidikan bagi penulis

3. Pimpinan, para pengajar, staf dan seluruh siswa SMK di Kabupaten HSU, atas bantuan dan kerjasamanya dalam penelitian ini.

4. Seluruh pihak yang tidak bisa disebutkan satu persatu.

Semoga segala daya upaya yang telah dicurahkan mendapat balasan berupa rahmat dan berbagai kemudahan serta hal terbaik lainnya dari Allah SWT, amin.

\section{DAFTAR PUSTAKA}

Clarke, L and Winch. C. (2007). Vocational Education International Approach, Development and System. New York: Routledge.

Cunningham. I, Dewea. G \& Bennett. B. (2004). The Hand Book of Work Based Learning. Burlington USA: Gower Publishing Company.

Customers Service Institute Of Australia. (2005). Work readiness. Diambil tanggal 28 Novenber 2011, dari http://www.wsc.edu.au/_docs/22Work readiness.pdf.

David Boud \& Nicky Solomon. (2003). Work Based Learning A New Higher Education. Buckingham: Published By SRHE and Open University Press Celtic Court.

Dirjen Peningkatan Mutu Tendik. (2007). Pedoman Manajemen Unit Produksi dan Jasa Sebagai Sumber Belajar Siswa Dan Penggalian Pendanaan Pendidikan. Jakarta: Depdiknas.

Finch, R., Curtis. \& Crunkilton, R., John. (1999). Curriculum development in vocational and technical education: Planning, content, and implementation. Needham Heights, MA. Boston: Allyn \& Bacon.
Gasskov, Vladimir. (2000). Managing Vocational Training System: Hand Book For Senior Administrators. Geneva: International Labaour Office.

Guruvalah. (1998). Kepala Sekolah Sebagai Wirausaha. Diambil dari (www.geocities.ws/guruvalah/entrepr eneur_kepsek.html) Pada Tanggal 12 Agustus 2011, Pukul 14. 20 WIB.

Kathy B. Grant \& Julie A. Ray. (2010). Home, School, and Community Collaboration. United State Of America: SAGE Publication, Inc.

Hasbullah. (2009). Dasar-Dasar Ilmu Pendidikan (umum dan agama islam). Jakarta: Rajawali Pers.

Issac and Michael JWB. (1984). Hand Book In Research and Evaluation. Second Edition. San Diago: GDITS Publisher.

Martubi. (1999). Model- model Penyelenggaraan Unit Produksi Di DIY. Laporan Hasil Penelitian Direktorat Pengabdian Masyarakat IKIP Yogyakarta, dimuat dalam jurnal No 1, Tahun XXIX IKIP Yogyakarta

Stephen A. \& Timothy P. (2004) Training And Development Enhanching Communication and Leadership Skills. New York: Pearson Education Inc.

Van Zolingen, S. J. (2002). The Role Key Qualification in the Transistion From Vocational Education to Work. Journal Of Vocation Research, Vol 2, $2,4$.

Wardiman. J. (1998). Pengembangan Sumber Daya Manusia Melalui Sekolah Menengah Kejuruan. Jakarta: PT Jayakarta Agung Offset

Zirkle, Chris. (1998). Perception of Vocational Educators And Human Resource/ Training and Development Profesisonals Regarding Skills Dimension of School to Work transsitin Programs. Journal of Vocational and Technical Education, Vol $15,1,4$. 